\title{
Glucagon-like peptide-1 receptor agonist ameliorates renal injury through its anti-inflammatory action without lowering blood glucose level in a rat model of type 1 diabetes
}

\author{
R. Kodera $\cdot$ K. Shikata $\cdot$ H. U. Kataoka $\cdot$ T. Takatsuka • \\ S. Miyamoto • M. Sasaki • N. Kajitani • S. Nishishita • \\ K. Sarai $\cdot$ D. Hirota $\cdot$ C. Sato $\cdot$ D. Ogawa $\cdot$ H. Makino
}

Received: 4 June 2010 / Accepted: 30 November 2010 / Published online: 21 January 2011

(C) Springer-Verlag 2011

\begin{abstract}
Aims/hypothesis Glucagon-like peptide-1 (GLP-1) has various extra-pancreatic actions, in addition to its enhancement of insulin secretion from pancreatic beta cells. The GLP-1 receptor is produced in kidney tissue. However, the direct effect of GLP-1 on diabetic nephropathy remains unclear. Here we demonstrate that a GLP-1 receptor agonist, exendin-4, exerts renoprotective effects through its antiinflammatory action via the GLP-1 receptor without lowering blood glucose.

Methods We administered exendin-4 at $10 \mu \mathrm{g} / \mathrm{kg}$ body weight daily for 8 weeks to a streptozotocin-induced rat model of type 1 diabetes and evaluated their urinary albumin excretion, metabolic data, histology and morphometry. We also examined the direct effects of exendin- 4 on glomerular endothelial cells and macrophages in vitro.
\end{abstract}

Electronic supplementary material The online version of this article (doi:10.1007/s00125-010-2028-x) contains supplementary material, which is available to authorised users.

R. Kodera $\cdot$ K. Shikata $(\bowtie) \cdot$ H. U. Kataoka $\cdot$ T. Takatsuka

S. Miyamoto $\cdot$ M. Sasaki $\cdot$ N. Kajitani $\cdot$ S. Nishishita $\cdot$ K. Sarai $\cdot$

D. Hirota $\cdot$ C. Sato $\cdot$ H. Makino

Department of Medicine and Clinical Science,

Okayama University Graduate School of Medicine, Dentistry,

and Pharmaceutical Sciences,

2-5-1 Shikata-cho,

Okayama 700-8558, Japan

e-mail: shikata@md.okayama-u.ac.jp

C. Sato $\cdot$ D. Ogawa

Department of Diabetic Nephropathy, Okayama University

Graduate School of Medicine, Dentistry,

and Pharmaceutical Sciences,

Okayama, Japan
Results Exendin-4 ameliorated albuminuria, glomerular hyperfiltration, glomerular hypertrophy and mesangial matrix expansion in the diabetic rats without changing blood pressure or body weight. Exendin-4 also prevented macrophage infiltration, and decreased protein levels of intercellular adhesion molecule-1 (ICAM-1) and type IV collagen, as well as decreasing oxidative stress and nuclear factor- $\mathrm{KB}$ activation in kidney tissue. In addition, we found that the GLP-1 receptor was produced on monocytes/ macrophages and glomerular endothelial cells. We demonstrated that in vitro exendin-4 acted directly on the GLP-1 receptor, and attenuated release of pro-inflammatory cytokines from macrophages and ICAM-1 production on glomerular endothelial cells.

Conclusions/interpretation These results indicate that GLP1 receptor agonists may prevent disease progression in the early stage of diabetic nephropathy through direct effects on the GLP-1 receptor in kidney tissue.

Keywords Anti-inflammatory effect · Diabetic nephropathy · Exendin-4 - Glomerular endothelial cells . GLP-1 receptor agonist - Intercellular adhesion molecule-1 . Macrophage $\cdot$ Nuclear factor- $\mathrm{KB} \cdot$ Type 1 diabetic rats
Abbreviations
GLP-1 Glucagon-like peptide-1
GLP-1R Glucagon-like peptide-1 receptor
hGECs Human glomerular microvascular endothelial cells
ICAM-1 Intercellular adhesion molecule-1
NOX4 NADPH oxidase 4
NF- $\mathrm{KB}$ Nuclear factor- $\mathrm{kB}$
8-OHdG 8-Hydroxydeoxyguanosine 


\section{Introduction}

The number of patients with diabetes is increasing dramatically throughout the world, while diabetic nephropathy is the leading cause of end-stage renal disease in developed countries. In addition, chronic kidney disease contributes to development of cardiovascular disease and leads to an increase in all-cause mortality rates $[1,2]$. Therefore, prevention of renal insufficiency improves the prognosis of diabetic patients.

Numerous factors contribute to the development of diabetic nephropathy, such as glomerular hyperfiltration [3], which is mainly observed in early-stage nephropathy, oxidative stress [4], accumulation of AGEs [5], activation of protein kinase $C[6]$, acceleration of the polyol pathway and overexpression of TGF- $\beta$ [7]. Accumulating evidence also points to the critical role of the inflammatory process in the development of diabetic vascular complications, suggesting that microinflammation is a common mechanism in pathogenesis of diabetic nephropathy $[8,9]$. Furuta et al. [10] reported that infiltration of mononuclear cells was prominent in the glomeruli of patients with diabetic nephropathy. Our group has also reported similar results, as well as observing an increase in the production of cell adhesion molecules in the kidney of diabetic patients [11]. We found that intercellular adhesion molecule-1 (ICAM-1) played a key role in promoting macrophage infiltration in glomeruli from a rat model of diabetes [12], and using mice deficient in ICAM-1, we also showed that blockade of ICAM-1 activation ameliorated diabetic nephropathy [13]. Additionally, we showed that methotrexate, an immunosuppressant, ameliorated diabetic nephropathy and that antiinflammatory agents also had a beneficial effect on diabetic nephropathy [14]. Modulation of the inflammatory process prevents renal injury in animal models of diabetes, suggesting that microinflammation is a potential therapeutic target in diabetic nephropathy [14-17].

Glucagon-like peptide-1 (GLP-1) is a gut incretin hormone and currently considered an attractive agent for treatment of type 2 diabetes. It has various beneficial effects on pancreatic beta cells, such as enhancement of glucose-dependent insulin secretion [18], acceleration of beta cell proliferation and inhibition of beta cell apoptosis [19]. In the gut and hypothalamus, GLP-1 inhibits motility, gastric emptying [20] and central regulation of feeding [21], resulting in body weight loss [18]. However, native GLP-1 is rapidly degraded in the circulation by dipeptidylpeptidase-IV [22]. Today, dipeptidylpeptidase-IV-resistant, long-acting GLP-1 receptor (GLP-1R) agonists such as exendin-4 and liraglutide are available for type 2 diabetic patients. Previous reports have shown that GLP-1R is produced not only in the pancreas, gut and hypothalamus, but also in the kidney [23-25]. With respect to the effects of GLP-1 on the kidney, it has been reported that exendin- 4 ameliorated hypertension by regulating sodium excretion in tubular cells [26] and attenuated renal injury by improving metabolic anomalies in a mouse model of type 2 diabetes [25]. From these results, the amelioration of hypertension and metabolic anomalies by GLP-1 would seem to have a beneficial effect on diabetic nephropathy. In the present study, we focused on the direct effect of GLP-1 through GLP-1R in the kidney, independently of the numerous other effects of GLP-1, including its glucose-lowering action.

\section{Methods}

Animals

Male Sprague-Dawley rats (5 weeks old; Charles River, Yokohama, Japan) were divided into the following groups: (1) non-diabetes $(n=5)$; (2) non-diabetes treated with exendin-4 $(n=6)$; (3) diabetes $(n=6)$; and (4) diabetes treated with exendin-4 $(n=6)$. At the age of 5 weeks, the groups allocated to be made diabetic received intravenous injections of streptozotocin (Sigma-Aldrich, St Louis, MO, USA) at $65 \mathrm{mg} / \mathrm{kg}$ body weight in citrate buffer ( $\mathrm{pH}$ 4.5). We included only rats with blood glucose concentrations $>16 \mathrm{mmol} / \mathrm{l}$ at 3 and 7 days after streptozotocin injection in the diabetes groups. The nondiabetic groups received injections of citrate buffer alone. The two groups treated with exendin-4 were given exendin-4 (Bachem, Bubendorf, Switzerland) intraperitoneally at $10 \mu \mathrm{g} / \mathrm{kg}$ body weight daily for 8 weeks, starting at 1 week after the streptozotocin or citrate buffer injections. The placebo groups were given water alone using the same schedule as in the exendin- 4 treatment groups. All rats had free access to standard chow and tap water. All procedures were performed according to the Guidelines for Animal Experiments at Okayama University Medical School, the Japanese Government Animal Protection and Management Law and the Japanese Government Notification on Feeding and Safekeeping of Animals. All rats were killed at 9 weeks after induction of diabetes in the diabetes groups, and the kidneys were weighed and fixed in 10\% (vol./vol.) formalin, or frozen in acetone cooled on dry ice.

Metabolic variables

Systolic BP was measured by tail-cuff plethysmography (Softron, Tokyo, Japan). $\mathrm{HbA}_{1 \mathrm{c}}$ was measured by the HPLC method. Serum creatinine was measured by the 3 -hydroxy2,4,6-triiodobenzoic acid method. Food intake was calculat- 
ed as the average over 3 days. Insulin concentration was measured by a rat insulin RIA kit (LincoResearch, St Charles, MO, USA). Urine samples were collected over a $24 \mathrm{~h}$ period in individual metabolism cages. Urinary albumin excretion was measured by nephelometry using anti-rat albumin antibody (ICN Pharmaceuticals, Aurora, $\mathrm{OH}$, USA). Creatinine clearance ( $\mathrm{ml} \mathrm{min} \mathrm{mg}^{-1}$ ) was calculated as described previously [15].

\section{Light microscopy}

The glomerular tuft area and mesangial matrix index (ratio of the mesangial matrix area/glomerular tuft area) were measured using a software package (Lumina Vision; Mitani, Fukui, Japan) as described previously [13]. Periodic acid-Schiff's reagent staining was used to observe the interstitium of the kidney. Quantitative analysis for all staining was performed in a blinded manner.

\section{Immunoperoxidase staining}

Immunoperoxidase staining was performed as described [12, 27]. Primary antibodies were macrophages mouse antibody (ED1, 1:50; Serotec, Oxford, UK), 8-hydroxydeoxyguanosin (8-OHdG) mouse antibody (1:10; JalCA, Shizuoka, Japan), NADPH oxidase 4 (NOX4) rabbit antibody (1:300; Novus Biologicals, Littleton, CO, USA) or GLP-1R rabbit antibody (ab39072, 1:200; Abcam, Tokyo, Japan), all of which were applied for $12 \mathrm{~h}$ at $4^{\circ} \mathrm{C}$. Secondary antibodies were biotinlabelled anti-mouse or anti-rabbit IgG (Jackson ImmunoResearch, West Grove, PA, USA), which were applied for $60 \mathrm{~min}$ at room temperature. The average number of ED1positive cells per glomerulus was used for the estimation. The ratio of the area stained positive with each of the above antibodies to the glomerular tuft area was calculated with a software package (Lumina Vision).
Immunofluorescence staining

Immunofluorescence staining was performed as described [12]. The primary antibodies were ICAM-1 mouse antibody (1:25; Abcam) or type IV collagen rabbit antibody (1:200; LSL, Tokyo, Japan), which were applied for $60 \mathrm{~min}$ at room temperature. Secondary antibodies were FITC-conjugated anti-mouse or anti-rabbit IgG (1:150; Zymed Laboratories, San Francisco, CA, USA), which were applied for $30 \mathrm{~min}$ at room temperature. Micrographic fluorescence photos were obtained with a laser-scanning confocal microscope (LSM510; Carl Zeiss, Jena, Germany). The ICAM-1 and type IV collagen indexes were calculated as described [15].

Double immunofluorescence staining

The primary antibodies were GLP-1R rabbit antibody (1:200; Abcam) and rat endothelial cell antigen (RECA-1, 1:40; Monosan, Uden, the Netherlands), macrophages (ED1, 1:50) mouse antibody, or NOX4 rabbit antibody (1:300), which were applied for $12 \mathrm{~h}$ at $4^{\circ} \mathrm{C}$. The secondary antibodies were Alexa-Fluor 488-labelled anti-rabbit and 546-labelled anti-mouse IgG (1:400; Invitrogen, Carlsbad, CA, USA), which were applied for $30 \mathrm{~min}$ at room temperature. Nuclei were stained with DAPI (Millipore, Tokyo, Japan). The sections were observed under a fluorescence microscope (BZ-800; Keyence, Osaka, Japan).

\section{Quantitative real-time RT-PCR and gene expression}

Total RNA was extracted from each sample (the rat renal cortex, glomeruli isolated by a previously reported mechanical sieving technique [28] and cultured cells) using a kit (RNeasy plus Mini; Qiagen, Valencia, CA, USA). Singlestrand cDNA was synthesised from the individual samples of total RNA at $1 \mu \mathrm{g}$ using a kit (GeneAmp RNA PCR-

Table 1 Metabolic variables of four rat groups at 8 weeks

\begin{tabular}{lcccc}
\hline Variable & Non-diabetic & & Diabetic \\
\cline { 2 - 4 } & Placebo & Exendin-4 & Placebo \\
\hline Body weight (g) & $471 \pm 23.5^{\mathrm{a}}$ & $397 \pm 8.3^{\mathrm{b}}$ & $256 \pm 30.5$ & Exendin-4 \\
Food intake (g/day) & $27.6 \pm 0.9^{\mathrm{c}, \mathrm{d}}$ & $19.3 \pm 3.1^{\mathrm{a}}$ & $44.6 \pm 12.5$ & $246 \pm 22.9$ \\
HbA $_{1 \mathrm{c}}(\%)$ & $3.7 \pm 0.1^{\mathrm{a}}$ & $3.9 \pm 0.1^{\mathrm{a}}$ & $10.5 \pm 0.5$ & $10.0 \pm 0.8$ \\
Fasting blood glucose (mmol/l) & $4.0 \pm 0.2^{\mathrm{a}}$ & $4.9 \pm 0.3^{\mathrm{a}}$ & $26.6 \pm 0.9$ & $120 \pm 1.3$ \\
Systolic BP (mmHg) & $115 \pm 2.6$ & $114 \pm 1.5$ & $11.6 \pm 0.7$ & $123 \pm 2.6$ \\
Relative kidney weight $(\mathrm{g} / \mathrm{kg})$ & $5.9 \pm 0.2^{\mathrm{a}}$ & $6.1 \pm 0.1^{\mathrm{a}}$ & $12.0 \pm 0.7$
\end{tabular}

Values are the means \pm SEM; $n=5$ animals in the non-diabetic placebo group; $n=6$ animals per group in the three other groups

${ }^{\mathrm{a}} p<0.001$ vs diabetes and diabetes + exendin- 4 groups $;{ }^{\mathrm{b}} p<0.01$ vs diabetes and diabetes + exendin- 4 groups; ${ }^{\mathrm{c}} p<0.001$ vs diabetes placebo group; ${ }^{\mathrm{d}} p<$ 0.05 vs diabetes plus exendin-4 group 
a

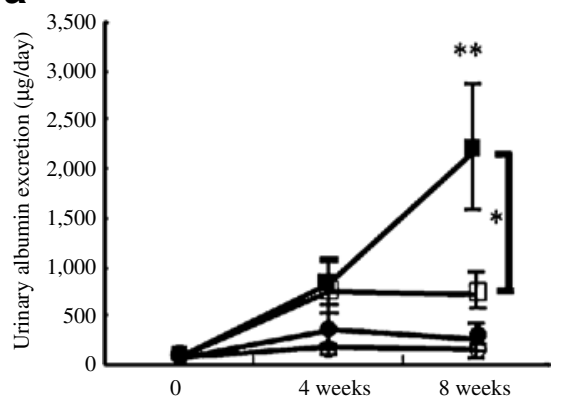

b

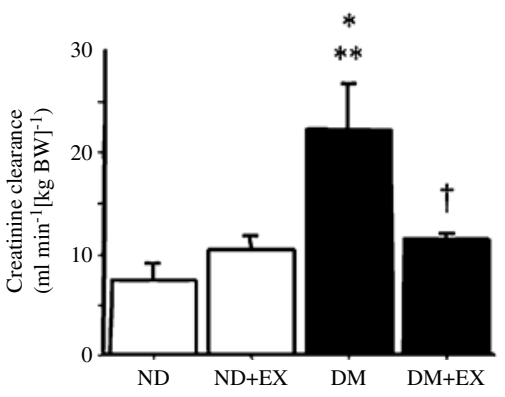

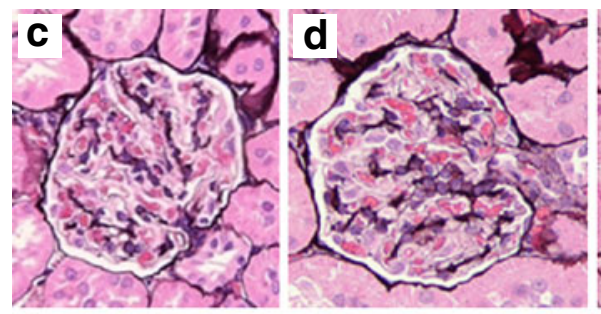
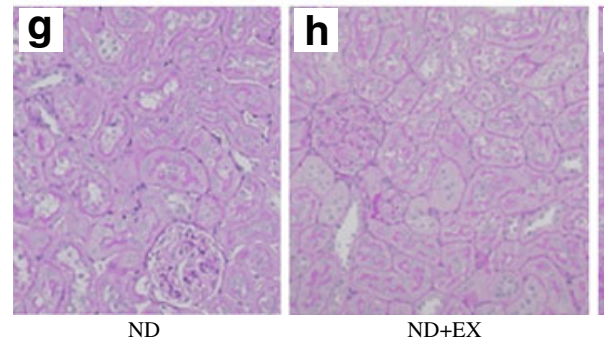

k

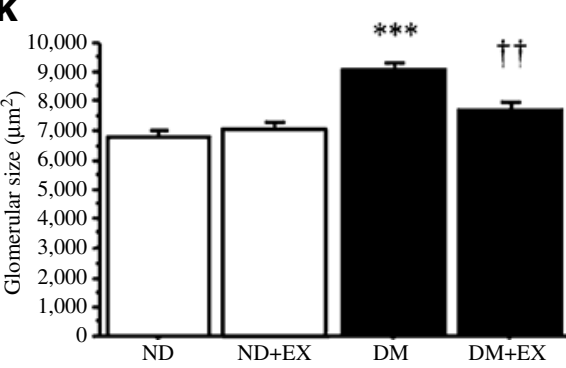

Fig. 1 a Time course of $24 \mathrm{~h}$ urinary albumin excretion. Urinary albumin excretion increased gradually over 8 weeks in the diabetic group. Exendin-4 resulted in a significantly lower level of urinary albumin excretion at 8 weeks than in the untreated diabetes group. ${ }^{*} p$ $<0.05 ;{ }^{*} p<0.01$ vs non-diabetic and non-diabetic + exendin-4 groups. Black circles, non-diabetic group; white circles, non-diabetic + exendin-4; black squares, streptozotocin-induced diabetes group; white squares, diabetes + exendin- 4 group. b Creatinine clearance. Hyperfiltration in the diabetic (DM) nephropathy group was significantly decreased by exendin- 4 treatment $(\mathrm{DM}+\mathrm{EX})$ at 8 weeks. ${ }^{*} p<$ 0.05 vs non-diabetic + exendin-4 (ND+EX); ${ }^{* *} p<0.01$ vs ND; ${ }^{\dagger} p<$ 0.05 vs DM. c-f Periodic acid-methenamine-silver (PAM) staining in

Core kit; Applied Biosystems, Foster City, CA, USA). After addition of each set of primers (final concentration $0.4 \mu \mathrm{mol} / 1$ ) and template DNA to the master mix, quantitative real-time RT-PCR was performed with a LightCycler (Roche Diagnostics, Tokyo, Japan) and
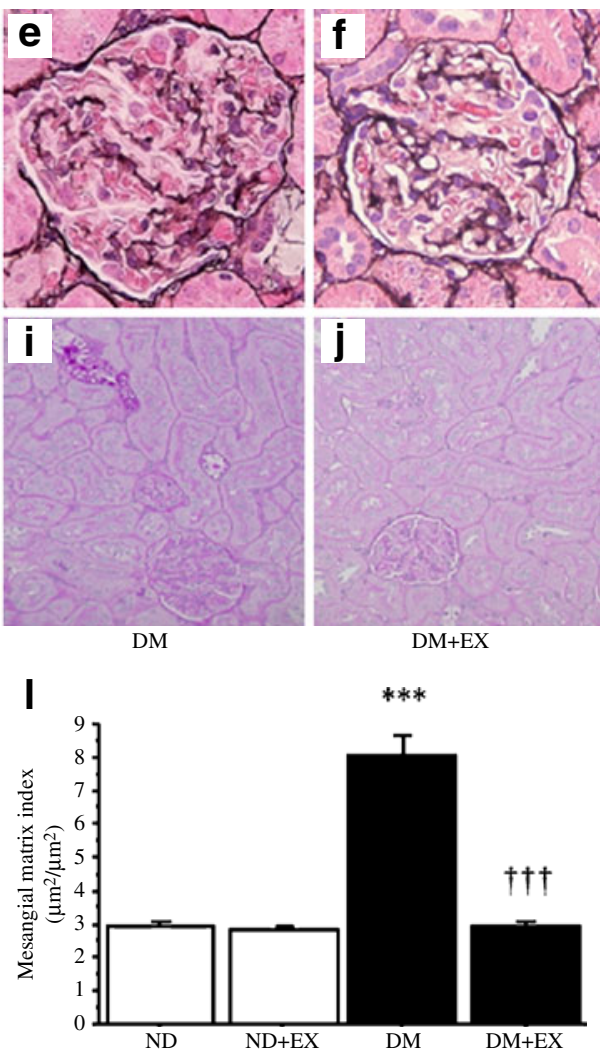

glomeruli (original magnification $\times 200$ ). $\mathbf{g}$-j Periodic acid-Schiff's reagent staining in the kidney $(\times 100)$. $\mathbf{k}$ Glomerular size (tuft area). Glomerular hypertrophy was significantly greater in the DM group than in the ND groups. Exendin-4 treatment significantly suppressed glomerular hypertrophy. ${ }^{* * *} p<0.001$ vs ND and ND+EX; ${ }^{\dagger \dagger} p<0.01$ vs DM. I Mesangial matrix index, calculated by the PAM-positive area in the tuft area, was significantly increased in the DM group. Exendin4 treatment significantly reduced mesangial matrix expansion. $* * * p<$ 0.001 vs ND and ND+EX; ${ }^{\dagger \dagger} p<0.001$ vs DM. $n=5$ animals in the untreated ND group; $n=6$ animals per group in the three other groups. k, I Glomeruli: $n=30$ from each rat kidney; $n=4$ per group. Values are the means \pm SEM

SYBR Premix-Ex-Taq (Takara Bio, Shiga, Japan). The PCR protocol was as follows: initial denaturation $\left(95^{\circ} \mathrm{C}\right.$ for $30 \mathrm{~s}$ ), followed by 40 cycles of denaturation $\left(95^{\circ} \mathrm{C}\right.$ for $5 \mathrm{~s})$, and annealing and extension $\left(60^{\circ} \mathrm{C}\right.$ for $\left.20 \mathrm{~s}\right)$. The specific oligonucleotide primer sequences are shown in 
Electronic supplementary material (ESM) Table 1. To visualise gene expression, individual DNA fragments were electrophoresed on a $2 \%$ (wt./vol) agarose gel (SigmaAldrich) and treated with ethidium bromide. cDNAs of the human pancreas (Takara Bio) and of rat islet-cell tumour cells (RIN-5F; DS Pharma Biomedical, Osaka, Japan) were used as positive controls.

\section{Urinary 8-OHdG excretion}

8-OHdG is a marker of oxidative DNA damage [29]. Urinary $8-\mathrm{OHdG}$ concentration in a $24 \mathrm{~h}$ urine collection was measured with a kit (8-OHdG ELISA; JalCA) according to the manufacturer's instructions.

\section{Nuclear factor-kB activation}

Nuclear proteins of kidney tissues were extracted by a nuclear extract kit and nuclear factor- $\mathrm{kB}$ (NF-kB) p65 activity determined by ELISA using reagents (Active-Motif; Carlsbad, CA, USA) according to the manufacturer's instructions. Absorbance was normalised to milligram cell protein.

\section{Western blotting}

Cells were lysed with cell lysis buffer containing $10 \mathrm{mmol} / 1$ TRIS (pH 7.4), 1\% (vol./vol.) Triton X-100, 0.5\% (vol./vol.) Nonidet P-40 and phosphatase inhibitor cocktail, $150 \mathrm{mmol} / 1$ $\mathrm{NaCl}, 1 \mathrm{mmol} / \mathrm{l}$ EDTA, $0.2 \mathrm{mmol} / \mathrm{l}$ EGTA, vanadate and phenylmethanesulfonyl fluoride. The cell lysates were subjected to 7.5\% SDS-PAGE (Bio-Rad Japan, Tokyo, Japan). The separated proteins were transferred to polyvinylidene fluoride membranes (Bio-Rad) by electrotransfer. The blots were subsequently blocked with 5\% (vol./vol.) skimmed milk (Nacalai Tesque, Kyoto, Japan) and then incubated with GLP$1 \mathrm{R}$ rabbit antibody (1:500; Abcam) and ICAM-1 mouse antibody $\left(1: 100 ;\right.$ Abcam) for $12 \mathrm{~h}$ at $4^{\circ} \mathrm{C}$, or with $\beta$-actin rabbit antibody (1:1,000; Sigma-Aldrich) for $1 \mathrm{~h}$ at room temperature. The membrane was incubated with horseradishperoxidase-linked donkey anti-rabbit or anti-mouse IgG (1:5,000; GE Healthcare Japan, Tokyo, Japan) at room temperature for $2 \mathrm{~h}$. The blots were then visualised with a western blotting detection system (ECL plus; GE Healthcare).

Culture

Human glomerular microvascular endothelial cells (hGECs) (ACBRI, Kirkland, WA, USA) were cultured in EGM-MV2 medium (Cambrex, East Rutherford, NJ, USA) supplemented with $19.4 \mathrm{mmol} / 1$ D-glucose, $10 \%$ (vol./vol.) FCS and growth factor within a gelatin-precoated flask in a $5 \%$ $\mathrm{CO}_{2}$ incubator at $37^{\circ} \mathrm{C}$.
THP-1 cells (a human monocytic cell line; JCRB, Tokyo, Japan) were cultured in RPMI 1640 supplemented with $10 \mathrm{mmol} / 1 \mathrm{D}$-glucose, $10 \% \mathrm{FCS}$ and growth factor in a $5 \% \mathrm{CO}_{2}$ incubator at $37^{\circ} \mathrm{C}$.

Human circulating monocytes

The human circulating monocytes were extracted using lymphocyte separation medium (MP Biomedicals, Tokyo, Japan) according to the manufacturer's instructions. After incubation in RPMI 1640 with $50 \mathrm{ng} / \mathrm{ml}$ phorbol myristate acetate (Sigma-Aldrich) for $24 \mathrm{~h}$, total RNA was collected from the attaching cells as described above.

The effects of GLP-1 in THP-1 cells

THP-1 cells $\left(1 \times 10^{6}\right.$ cells $\left./ \mathrm{ml}\right)$ were incubated for $24 \mathrm{~h}$ in six-well plates in RPMI 1640 medium supplemented with $1 \%$ FCS and $5.5 \mathrm{mmol} / 1 \mathrm{D}$-glucose. THP-1 cells were exposed to the following conditions: (1) $5.5 \mathrm{mmol} / \mathrm{l} \mathrm{D-}$ glucose (normal glucose); (2) $5.5 \mathrm{mmol} / \mathrm{l}$ D-glucose with $9.5 \mathrm{mmol} / \mathrm{l}$ mannitol (osmotic control); (3) $15 \mathrm{mmol} / \mathrm{l} \mathrm{D}-$ glucose (high glucose); (4) high glucose with $2.5 \mathrm{nmol} / \mathrm{l}$ exendin-4; (5) high glucose with $10 \mathrm{nmol} / 1$ exendin-4; (6) high glucose with $100 \mathrm{nmol} / \mathrm{l}$ exendin-4; and (7) high glucose with $100 \mathrm{nmol} / \mathrm{l}$ exendin-4 and $1000 \mathrm{nmol} / \mathrm{l} \mathrm{GLP}-$ $1 \mathrm{R}$ antagonist (9-39) (Bachem). After incubation for $72 \mathrm{~h}$, total RNA and supernatant fractions were collected from the cells. The supernatant fractions were measured using a human TNF- $\alpha$ and IL-1 $\beta$ immunoassay (Quantikine; R\&D Systems, Minneapolis, MN, USA) according to the manufacturer's instructions.

\section{The effect of GLP-1 in hGECs}

After starvation for $12 \mathrm{~h}$, hGECs were exposed to the following conditions: (1) no TNF- $\alpha$ stimulation (control); (2) $100 \mathrm{pg} / \mathrm{ml} \mathrm{TNF}-\alpha$ alone; (3) TNF- $\alpha$ with $2.5 \mathrm{nmol} / 1$ exendin-4; (4) TNF- $\alpha$ with $10 \mathrm{nmol} / 1$ exendin-4; (5) TNF- $\alpha$ with $100 \mathrm{nmol} / \mathrm{l}$ exendin-4; and (6) TNF- $\alpha$ with $100 \mathrm{nmol} / 1$ exendin-4 and $1000 \mathrm{nmol} / \mathrm{l} \mathrm{GLP}-1 \mathrm{R}$ antagonist (9-39). After incubation for $6 \mathrm{~h}$, total RNA and protein were collected from cells as described above. Recombinant human TNF- $\alpha$ was purchased from R\&D Systems.

Statistical analysis

All values are expressed as the means \pm SEM. Differences between groups were examined for statistical significance using the Mann-Whitney test or one-way ANOVA followed by Scheffe's test. Values of $p<0.05$ were considered to indicate statistically significant differences. 

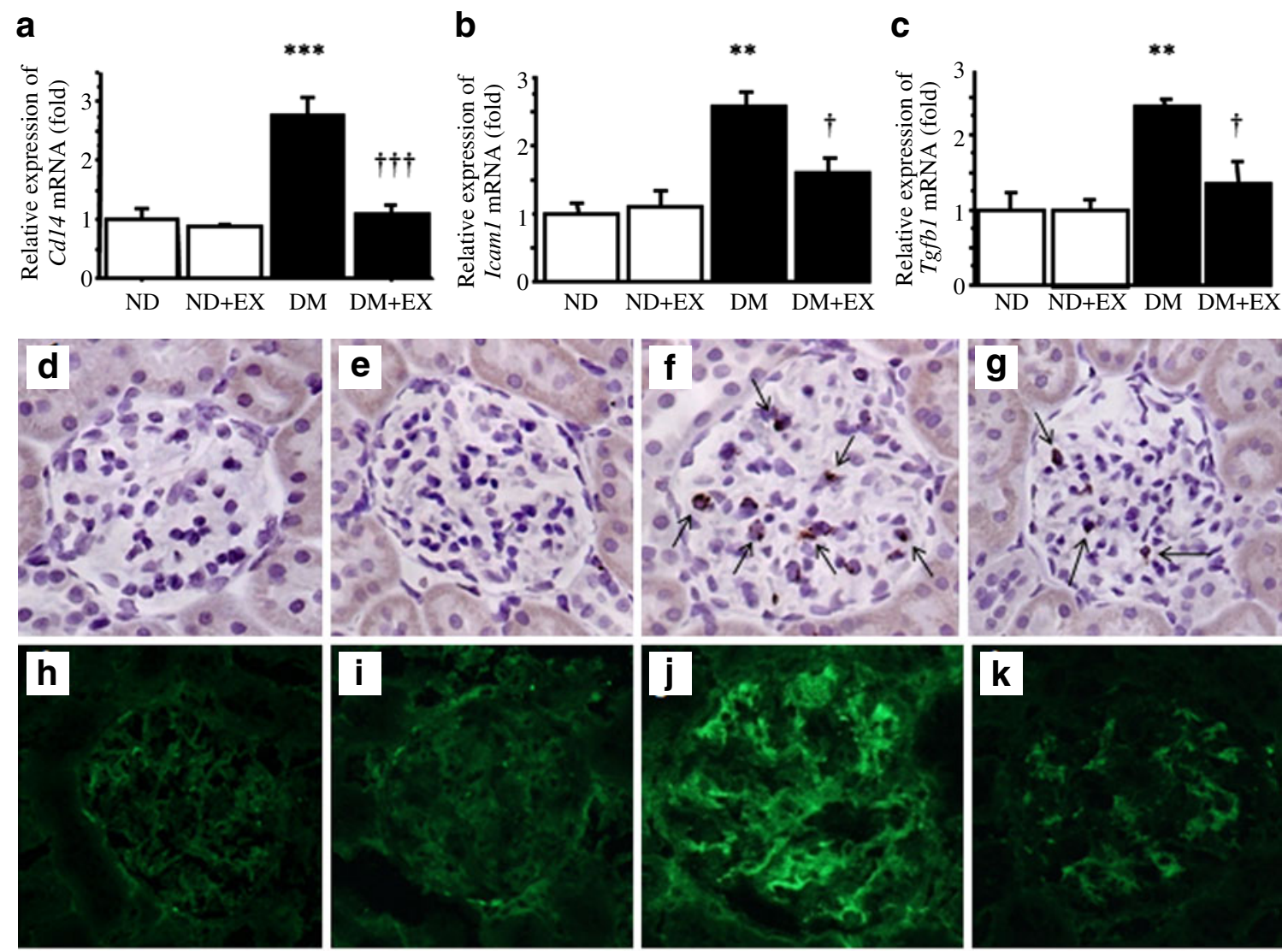

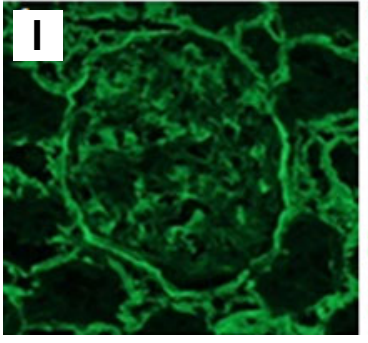

ND

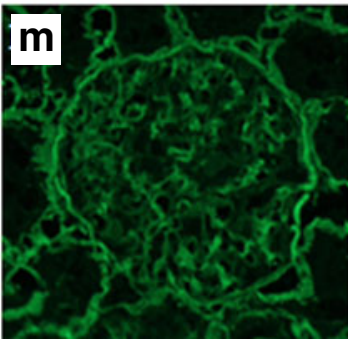

$\mathrm{ND}+\mathrm{EX}$

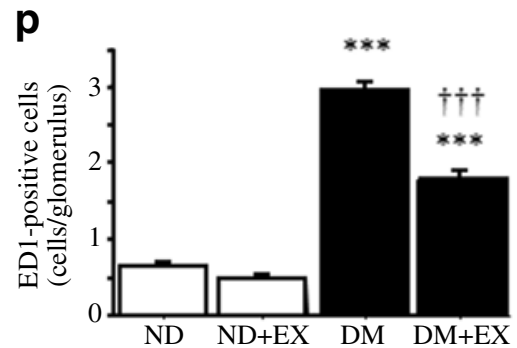

9

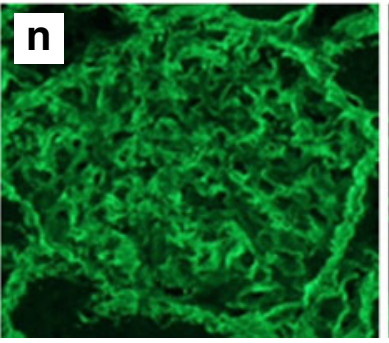

DM

$\boldsymbol{r}$

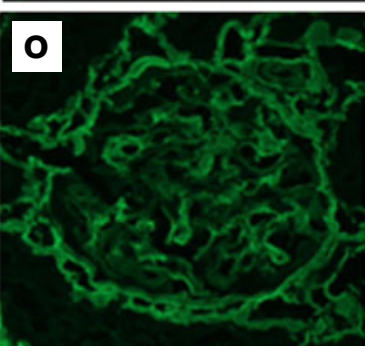

$\mathrm{DM}+\mathrm{EX}$
Fig. 2 Exendin-4 treatment suppressed the inflammatory axis in the kidney. a Quantification of Cd14, (b) Icaml and (c) Tgfbl gene expression by real-time RT-PCR in the renal cortex. All three genes were significantly downregulated by exendin-4 treatment. Values (means \pm SEM) are presented as fold relative to Actb and expressed as 1 in ND; $n=4$ per group. Each experiment was performed three times. $* * p<0.01$ and $* * * p<0.001$ vs non-diabetic (ND) and ND + exendin-4 (EX); ${ }^{\dagger} p<0.05$ and ${ }^{\dagger \dagger} p<0.001$ vs diabetes (DM). d-g Immunoperoxidase staining for macrophages (ED1-positive cells), indicated by arrows. $\mathbf{h}-\mathbf{k}$ Immunofluorescence staining for ICAM-1 and (1-o) for type IV collagen. Magnification, all images $\times 200$. p Quantification of the number of macrophages per glomerulus, which was significantly increased in the diabetic groups. Exendin-4 treatment significantly prevented glomerular macrophage infiltration in diabetes. $* * * p<0.001$ vs ND and ND+EX; ${ }^{\dagger \dagger} p<0.001$ vs DM. q Quantification of glomerular ICAM-1 staining per glomerulus, which was significantly increased in the diabetic groups and significantly reduced vs DM by exendin-4 treatment. $* * * p<0.001$ vs ND and ND+EX; ${ }^{\dagger \dagger} p<0.001$ vs DM. r Quantification of type IV collagen staining per glomerulus. Type IV collagen was significantly increased in the DM group and significantly reduced by exendin- 4 treatment. $* * * p<0.001$ vs ND and ND+EX; ${ }^{\dagger \dagger} p<0.001$ vs DM. p-r Values are the means \pm SEM; $n=20$ glomeruli from each rat kidney; $n=4$ per group. Each experiment was repeated three times 


\section{Results}

Metabolic variables and urinary albumin excretion

Body, organ weights and systolic BP As seen in Table 1, body weights of the diabetic groups at 8 weeks after initiation of exendin- 4 treatment were significantly lower than those of the non-diabetic groups. The kidney weights per body weight of the diabetic groups were significantly higher than those of the non-diabetic groups. There were no significant differences among the diabetic groups. Systolic BP was similar in all groups.

Food intake, $\mathrm{Hb}_{1 c}$ and insulin Food intake and $\mathrm{HbA}_{1 \mathrm{c}}$ were significantly elevated in the diabetic groups. However, there were no significant differences among the diabetic groups. Although GLP-1 has beta cell-protective effects, serum insulin concentration was not detectable in the diabetic groups in spite of the high blood glucose levels (data not shown).

Urinary albumin excretion and creatinine clearance Urinary albumin excretion, which is a characteristic feature of the early stage of diabetic nephropathy, increased progressively in the diabetic groups during the study. Exendin-4 treatment significantly reduced urinary albumin excretion compared with that of the diabetes group at 8 weeks (Fig. 1a). In addition, exendin-4 treatment prevented diabetes-induced hyperfiltration (Fig. 1b).

\section{Kidney morphology}

The level of glomerular hypertrophy was significantly higher in the diabetes group than in non-diabetic groups. In contrast, exendin-4 treatment inhibited glomerular hypertrophy (Fig. 1c-f, k) in diabetes. Quantitative analysis showed that mesangial matrix index, which was used as an index of mesangial expansion, was significantly increased in the diabetes group. However, exendin-4 treatment significantly reduced mesangial matrix expansion (Fig. 11). The renal interstitium showed a significantly higher level of tubular hypertrophy in the diabetic groups than in non-diabetic groups. However, there was no remarkable difference among the diabetic groups. In addition, no histological change of fibrosis in the renal interstitium was seen in any of the groups (Fig. 1g-j).

\section{Microinflammation in the kidney}

To evaluate the anti-inflammatory effect of exendin- 4 in the kidney, we examined gene expression of $\mathrm{Cd} 14$, which is regarded as a cell surface marker of macrophages, as well as expression of Icam 1 and $T g f b 1$ in the cortex. $C d 14$, Icam 1 and $T g f b l$ were significantly upregulated in the diabetes group and significantly downregulated by exendin4 treatment (Fig. 2a-c). Regarding the glomeruli, we evaluated macrophage infiltration, and ICAM-1 and type IV collagen levels in glomeruli. The number of macrophages in glomeruli was significantly elevated in the diabetic compared with the non-diabetic groups. In contrast, exendin-4 treatment significantly prevented glomerular macrophage infiltration (Fig. $2 \mathrm{~d}-\mathrm{g}, \mathrm{p}$ ) in diabetes. The ICAM-1 level was significantly increased in the diabetic groups, but was significantly reduced by exendin-4 treatment (Fig. 2h-k, q). The type IV collagen level, which is an important component in the mesangial matrix, was significantly increased in the diabetes group and significantly reduced by exendin-4 treatment (Fig. 2l-o, r).

Influence of exendin- 4 on oxidative stress

To evaluate oxidative stress, we focused on $8-\mathrm{OHdG}$ and NOX4. Urinary excretion of $8-\mathrm{OHdG}$ was significantly increased in the diabetic groups compared with the nondiabetic groups. Exendin-4 treatment significantly decreased urinary excretion of 8-OHdG in diabetes (Fig. 3a). Immunoperoxidase staining for $8-\mathrm{OHdG}$ revealed a significant abundance of 8-OHdG in glomeruli in the diabetic groups, which was significantly reduced by exendin- 4 treatment (Fig. 3b-e, j). Nox4 gene expression in the cortex was significantly upregulated in the diabetes group and significantly downregulated by exendin-4 treatment (Fig. 3k). We demonstrated the presence of NOX4 in glomerular endothelial cells in the rat kidney (ESM Fig. 1h-k). Immunoperoxidase staining for NOX4 revealed a significant abundance of NOX4 in the diabetic kidney. However, exendin-4 treatment significantly reduced the level of NOX4 in diabetes (Fig. 3f-i, l).

NF- $\mathrm{KB}$ activation in the kidney

The activation of NF-KB p65 DNA-binding activity was significantly enhanced in the diabetes compared with the nondiabetic groups. Exendin-4 treatment significantly inhibited NF-KB p65 DNA-binding activity in diabetes (Fig. 3m).

\section{GLP-1R in rat glomeruli}

We demonstrated the existence of GLP-1R in rat glomeruli (Fig. 4a, d). Double immunofluorescence staining revealed production of GLP-1R on glomerular endothelial cells (Fig. 4e-h). In addition, we ascertained that GLP-1R was produced on macrophages in rat glomeruli (Fig. 4i-1). The GLP-1R levels in glomeruli were not significantly different among the groups (ESM Fig. 1a-g). 


\section{a}
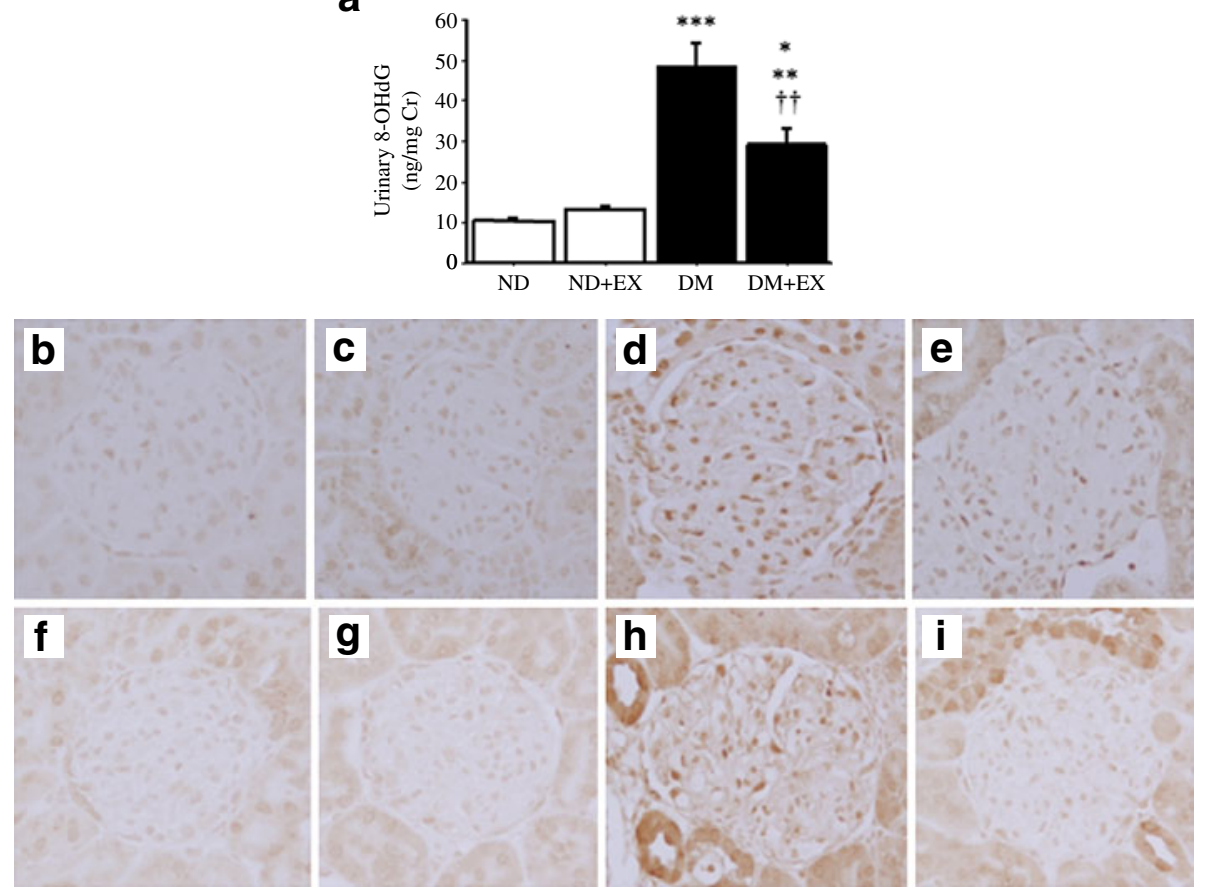

j

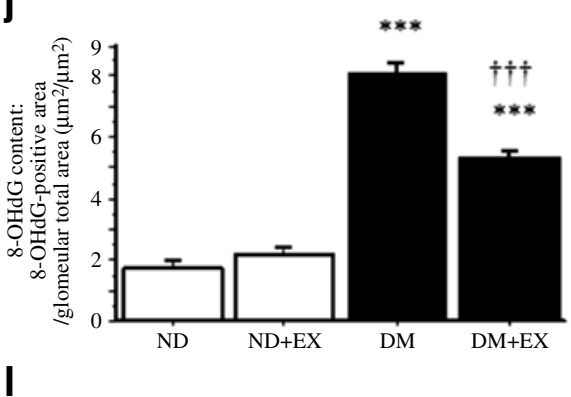

I

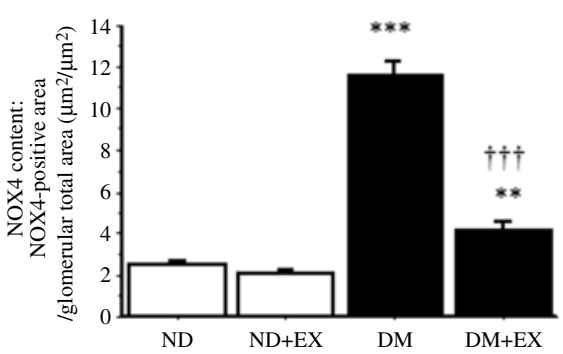

Fig. 3 Exendin-4 treatment suppressed oxidative stress and NF-kB activation. a Urinary $8-\mathrm{OHdG}$ concentration in a $24 \mathrm{~h}$ urine collection. Urinary 8-OHdG excretion was significantly increased in the diabetic groups (DM). However, exendin-4 treatment (EX) significantly decreased urinary 8 -OHdG excretion; $n=5$ per group. The experiment was repeated twice. ${ }^{*} p<0.05$ vs non-diabetic (ND)+EX; ${ }^{* *} p<0.01$ vs ND; ${ }^{* * *} p<0.001$ vs ND and ND+EX; ${ }^{\dagger} p<0.01$ vs DM. b-e Immunoperoxidase staining for $8-\mathrm{OHdG}$ and (f-i) NOX4 in glomeruli. Magnification, all images $\times 200$. j Quantification of $8-\mathrm{OHdG}$ content $\left(\mu \mathrm{m}^{2} / \mu \mathrm{m}^{2}\right)$ as staining per glomerulus. Glomerular $8-\mathrm{OHdG}$ content was significantly increased in the diabetic groups and significantly reduced by exendin- 4 treatment. Values are means \pm SEM; $n=20$ glomeruli from each rat kidney; $n=4$ per group. ${ }^{* * *} p<0.001$ vs ND and ND+EX; ${ }^{\dagger \dagger} p$ $<0.001$ vs DM. k Quantification of Nox4 by real-time RT-PCR in the k
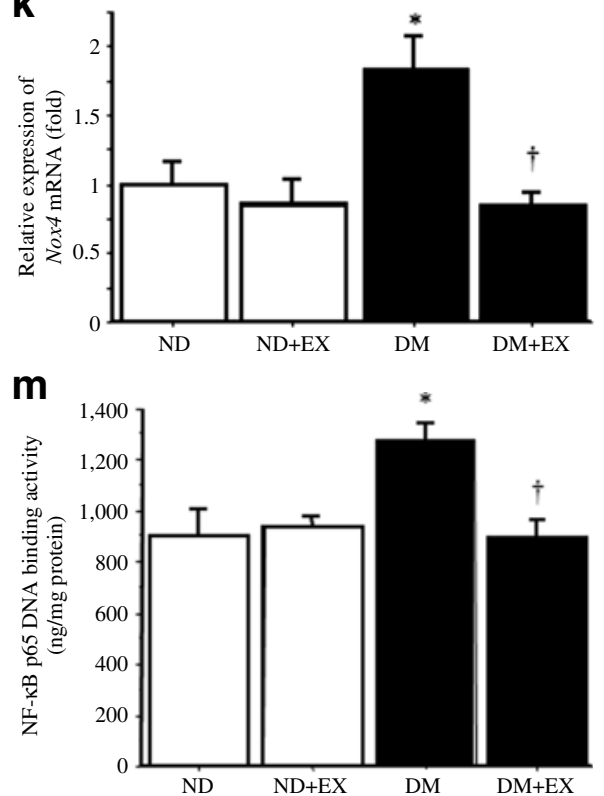

renal cortex. Nox4 expression was significantly downregulated by exendin-4 treatment. Values (means \pm SEM) are presented as fold relative to $A c t b$ and expressed as 1 in ND; $n=4$ per group. Each experiment was repeated three times. ${ }^{*} p<0.05$ vs ND and ND+EX; ${ }^{\dagger} p<$ 0.05 vs DM. I Quantification of NOX 4 content $\left(\mu \mathrm{m}^{2} / \mu \mathrm{m}^{2}\right)$ as staining per glomerulus. NOX4 content was significantly increased in the diabetic groups and significantly suppressed by exendin-4 treatment. Values are means \pm SEM; $n=20$ glomeruli from each rat kidney; $n=4$ per group. ${ }^{* *} p<0.01$ and $* * * p<0.001$ vs ND and ND+EX; ${ }^{\dagger \dagger} p<0.001$ vs DM. m NF-kB p65 DNA-binding activity. NF-kB p65DNA-binding activity was significantly increased in the DM group. Exendin-4 treatment significantly decreased NF-KB p65 DNA-binding activity. Values are the means $\pm \mathrm{SEM} ; n=5$ per group. The experiment was repeated twice. ${ }^{*} p<0.05$ vs ND and ND+EX; ${ }^{\dagger} p<0.05$ vs DM 
GLP-1R in human macrophages and hGECs

We identified the existence of GLP-1R in THP-1 cells and hGECs (Figs 5a, b and 6a, b). In addition, we examined GLP1R gene expression in human circulating monocytes. We demonstrated that the GLP-1R gene was not only expressed in the THP-1 cell line, but also in human circulating monocytes (Fig. 5a).

The effects of GLP-1 through GLP-1R on THP-1 cells and hGECs

THP-1 cells stimulated with a high concentration of glucose for $72 \mathrm{~h}$ showed significantly enhanced levels of TNF and $I L 1 B$ gene expression. Exendin-4 significantly and dosedependently attenuated $T N F$ and $I L I B$ gene expression. Additionally, the effects of exendin-4 were significantly blocked by a GLP-1R antagonist (Fig. 5c, d). Similarly, exendin-4 significantly suppressed TNF- $\alpha$ and IL-1 $\beta$ secretion from THP-1, effects that were also significantly blocked by the GLP-1R antagonist (Fig. 5e, f).

hGECs stimulated with TNF- $\alpha$ for $6 \mathrm{~h}$ showed significantly enhanced ICAMI gene expression. Exendin-4 significantly and dose-dependently attenuated ICAMI gene expression. In addition, the effect of exendin-4 was significantly blocked by the GLP-1R antagonist (Fig. 6c). Likewise, exendin-4 significantly suppressed TNF- $\alpha$ induced ICAM-1 production on hGECs, an effect that, again, was also significantly blocked by the GLP-1R antagonist (Fig. 6d, e).

\section{Discussion}

In the present study, we showed that exendin-4 exerted renoprotective effects through anti-inflammatory actions without lowering the blood glucose level in a streptozotocin-induced rat model of type 1 diabetes. In addition, exendin-4 inhibited NF- $\mathrm{KB}$ activity in the kidney, which is known to contribute to cross-talk between inflammation and oxidative stress. We also found that GLP-1R was produced in rat, and in cultured macrophages and glomerular endothelial cells. Exendin-4 acted directly on GLP-1R and attenuated production of pro-inflammatory cytokines and ICAM-1 in vitro. This is the first report of a GLP-1R agonist directly contributing, via its anti- a

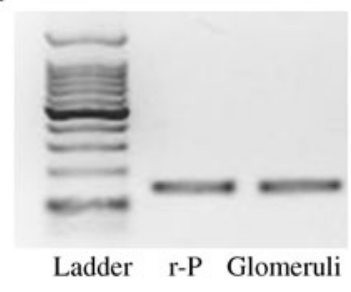

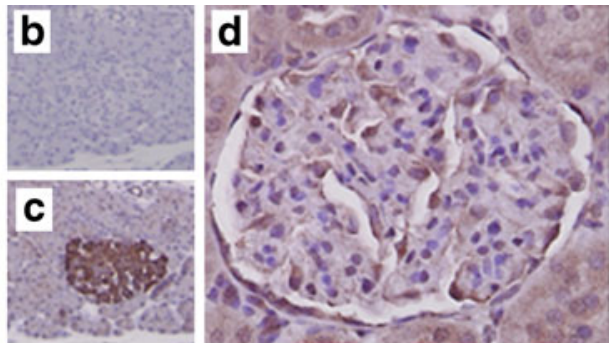

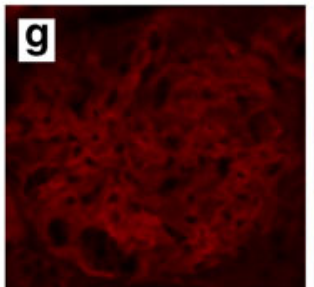

RECA-1

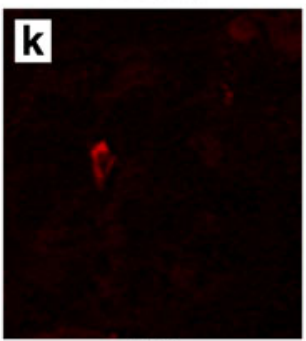

ED1

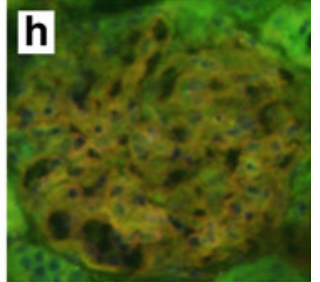

Merge

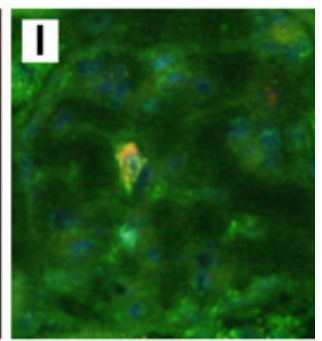

Merge

Fig. 4 The production of GLP-1R in rat glomeruli. a Glp1r gene expression in rat glomeruli. r-P: rat positive control (RIN-5F: rat isletcell tumour). b Immunoperoxidase staining for GLP-1R, with negative control in rat pancreas islet cells, (c) positive control in rat pancreas

islet cells and (d) rat glomeruli. e-h Double immunofluorescence staining for GLP-1R and glomerular endothelial cells as labelled. RECA-1, rat endothelial cell antigen. i-I Double immunofluorescence staining for GLP-1R and macrophages 
a

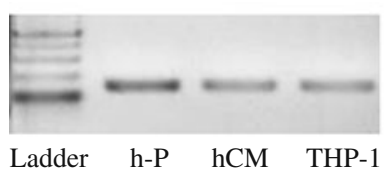

b

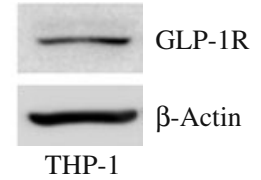

C

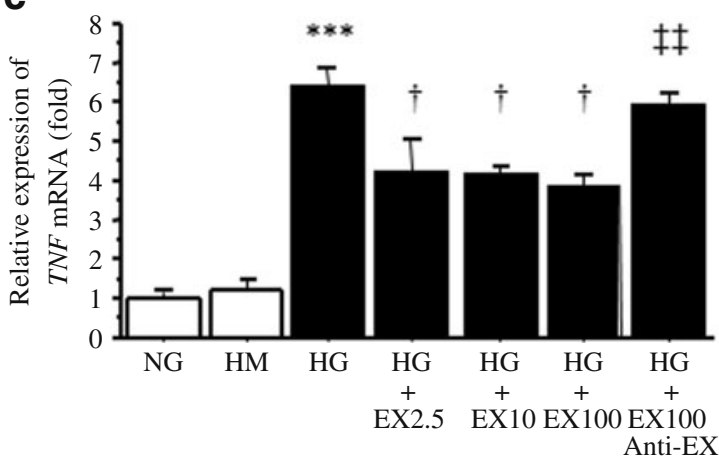

e

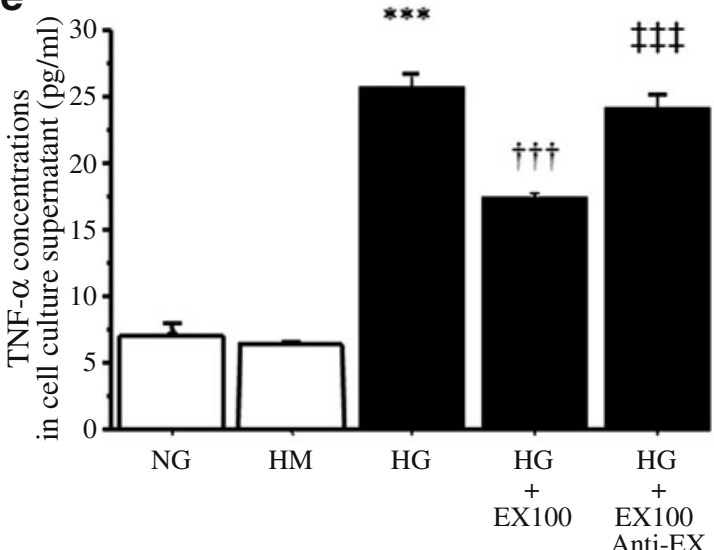

d

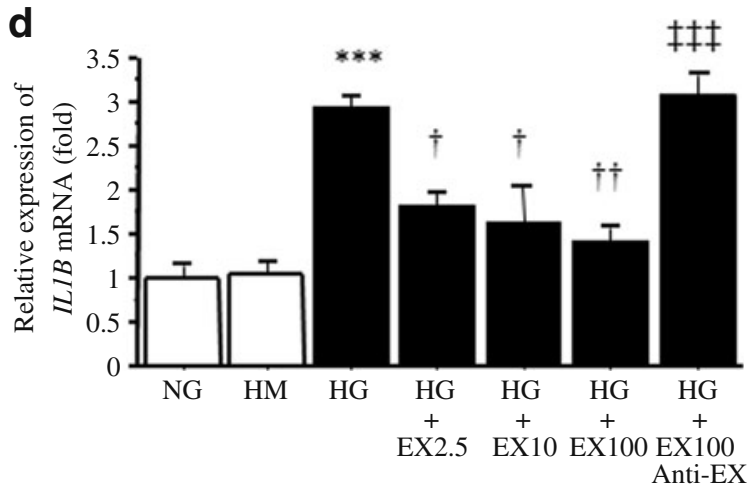

f

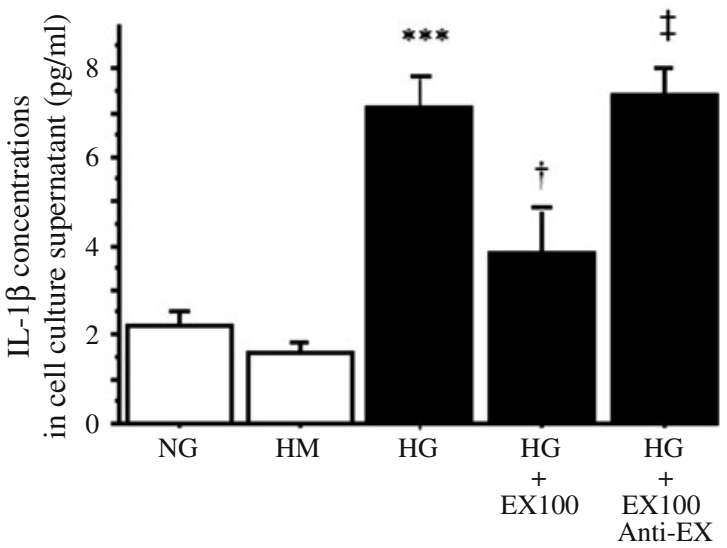

Fig. 5 The direct effects of exendin-4 on THP-1 cells. a GLP1R gene expression in human circulating monocytes (hCM) and THP-1 cells. h-P, human positive control (human pancreas). b GLP-1R protein production in THP-1 cells by western blotting. c Quantification of $T N F$ and (d) $I L 1 B$ mRNA expression in THP-1 by real-time RT-PCR. THP-1 cells stimulated with $15 \mathrm{mmol} / 1$ high glucose (HG; $15.0 \mathrm{mmol} /$ $1 \mathrm{D}$-glucose) for $72 \mathrm{~h}$ showed significantly enhanced TNF and ILIB expression. Exendin-4 (EX) significantly and dose-dependently suppressed $T N F$ and $I L 1 B$ gene expression. GLP-1R antagonist (anti-EX; $1,000 \mathrm{nmol} / \mathrm{l}$ ) significantly inhibited the suppressive effects of exendin-4 $(100 \mathrm{nmol} / \mathrm{l})$ on $T N F$ and $I L 1 B$ expression. Values (means \pm SEM) are presented as fold relative to $G A P D H$ and expressed as 1 in normal glucose (NG; $5.5 \mathrm{mmol} / \mathrm{l} \mathrm{D}$-glucose), $n=5$ per group. The experiment was repeated three times. ${ }^{* * *} p<0.001 \mathrm{vs} \mathrm{NG}$ and $5.5 \mathrm{mmol} / 1 \mathrm{D}-$ glucose with $9.5 \mathrm{mmol} / 1$ mannitol (HM); ${ }^{\dagger} p<0.05$ and ${ }^{\dagger \dagger} p<0.01$ vs HG; ${ }^{+1} p<0.01$ and ${ }^{\$ t} p<0.001 \mathrm{vs} \mathrm{HG}+\mathrm{EX}(100 \mathrm{nmol} / \mathrm{l} ; \mathrm{EX} 100)$. e Quantification of TNF- $\alpha$ and (f) IL- $1 \beta$ secretion (pg/ml) from THP1 by ELISA. Stimulation of THP-1 cells with HG for $72 \mathrm{~h}$ significantly promoted TNF- $\alpha$ and IL-1 $\beta$ secretion. Exendin-4 significantly suppressed TNF- $\alpha$ and IL-1 $\beta$ secretion. GLP-1R antagonist (anti-EX; $1,000 \mathrm{nmol} / \mathrm{l}$ ) significantly inhibited the suppressive effects of exendin-4 (100 nmol/l) on TNF- $\alpha$ and IL-1 $\beta$ secretion. Values are the means $\pm \mathrm{SEM} ; n=5$ per group. The experiment was repeated twice. ${ }^{* * *} p<0.001$ vs NG and $\mathrm{HM} ;{ }^{\dagger} p<$ 0.05 and ${ }^{\dagger \dagger} p<0.001$ vs HG; ${ }^{\star} p<0.05$ and ${ }^{+*} p<0.001$ vs HG+EX100. EX2.5, $2.5 \mathrm{nmol} / 1$ exendin-4; EX10, $10 \mathrm{nmol} / 1$ exendin-4 inflammatory effects, to amelioration of characteristic features of diabetic nephropathy, such as increased urinary albumin excretion, glomerular hypertrophy and mesangial matrix expansion.

The current results suggest that exendin- 4 alleviated the above-mentioned features by suppressing: (1) ICAM-1 production; (2) macrophage infiltration; (3) NF- $\mathrm{KB}$ activation; (4) oxidative stress; and (5) $T g f b 1$ mRNA expression and type IV collagen accumulation in the kidney.
An increase in the level of ICAM-1 on glomerular endothelial cells promotes macrophage infiltration into glomeruli [12, 14]. In our study, exendin-4 prevented macrophage infiltration into glomeruli. The mechanism underlying this effect was thought to be the suppression of ICAM-1 production on glomerular endothelial cells and direct inhibition of cytokine release from macrophages, which breaks the vicious cycle between macrophages and glomerular endothelial cells that gives rise to microinflam- 

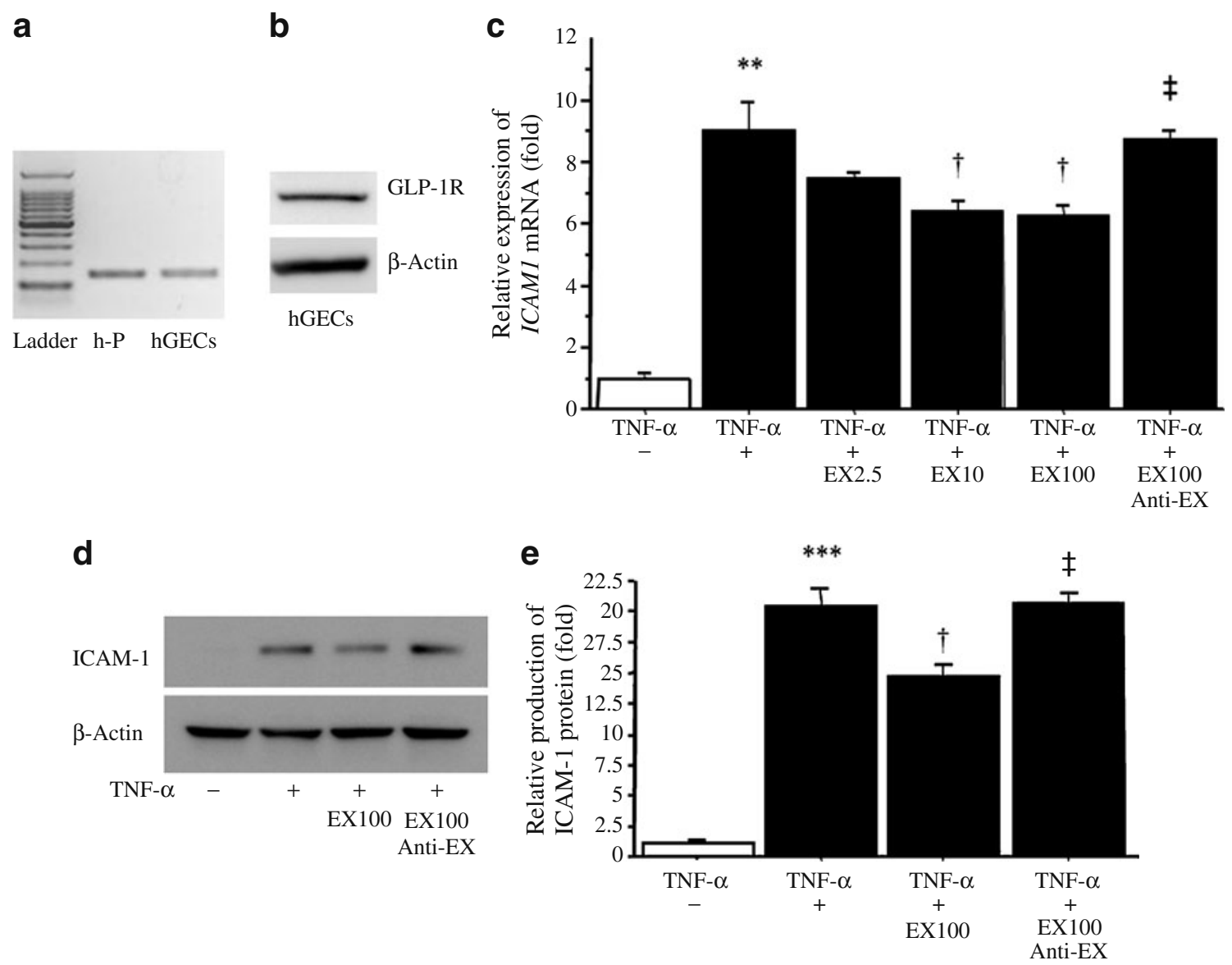

Fig. 6 The direct effects of exendin- 4 on hGECs. a GLP1R gene expression in hGECs. h-P, human positive control (human pancreas). b GLP-1R protein production in hGECs by western blotting. c Quantification of ICAMI expression in hGECs by real-time RT-PCR. hGECs stimulated with TNF- $\alpha(100 \mathrm{pg} / \mathrm{ml})$ for $6 \mathrm{~h}$ showed significantly enhanced ICAMI expression. Exendin-4 (EX) significantly and dose-dependently suppressed ICAMI gene expression. GLP-1R antagonist $(1,000 \mathrm{nmol} / \mathrm{l}$; anti-EX) significantly inhibited the suppressive effect of $100 \mathrm{nmol} / 1$ exendin-4 (EX100) on ICAM1 expression. Values (means $\pm \mathrm{SEM}$ ) are presented as fold relative to $A C T B$ and expressed as 1 in control (no TNF- $\alpha$ stimulation); $n=5$ per group. The experiment was repeated three times. ${ }^{* *} p<0.01$ vs

mation. In HUVECs, treatment with liraglutide, a longacting GLP-1 analogue, has also been shown to inhibit TNF- $\alpha$ or hyperglycaemia-mediated induction of ICAM-1 gene and protein [30]. These reports support our present findings. In our study, high glucose $(15 \mathrm{mmol} / \mathrm{l})$ stimulation for a period of 24 to $72 \mathrm{~h}$ did not significantly enhance ICAM1 gene expression in hGECs (data not shown).

Macrophages play a critical role in the development of diabetic nephropathy. In vitro, the culture supernatant fraction of macrophages has been shown to stimulate mesangial cells to produce fibronectin [31], while macrophages directly secrete TGF- $\beta$ [32]. Both of these processes play a central role in the enhancement of glomerular extracellular matrix production in diabetic nephropathy control; ${ }^{\dagger} p<0.05$ vs TNF- $\alpha$ stimulation; ${ }^{\dagger} p<0.05$ vs TNF- $\alpha+$ $100 \mathrm{nmol} / 1 \mathrm{EX}$ (EX100). d ICAM-1 production in hGECs by western blotting analysis, with (e) quantification. hGECs stimulated with TNF- $\alpha(100 \mathrm{pg} / \mathrm{ml})$ for $6 \mathrm{~h}$ significantly promoted ICAM-1 production. Exendin-4 significantly suppressed ICAM-1 production. Anti-EX significantly inhibited the suppressive effect of EX100 on ICAM-1 production. Values (means \pm SEM) are presented as fold relative to $\beta$-actin and expressed as 1 in control (no TNF- $\alpha$ stimulation); $n=5$ per group. The experiment was repeated twice. $* * * p<0.01$ vs control; ${ }^{\dagger} p<0.05$ vs TNF- $\alpha$ stimulation; ${ }^{\star} p<0.05$ vs TNF- $\alpha+$ EX100. EX2.5, $2.5 \mathrm{nmol} / 1$ exendin-4; EX10, $10 \mathrm{nmol} /$ 1 exendin-4

$[33,34]$. Based on these previous and our present findings, we conclude that the inhibition of macrophage infiltration by exendin- 4 has a beneficial effect on suppressing progression of diabetic nephropathy.

In the diabetic state, many factors contribute to elevated NF- $\mathrm{KB}$ activation [35]. NF- $\mathrm{kB}$ is also the most important transcription factor regulating ICAM-1 production [36]. Arakawa et al. [37] reported that exendin-4 suppressed NF$\mathrm{KB}$ activation of lipopolysaccharide-induced macrophages, suggesting that exendin- 4 reduced direct NF- $\mathrm{KB}$ activation in macrophages. The reduction of NF- $\mathrm{KB}$ activity by exendin-4 may lead to inhibition of ICAM-1 levels and suppression of pro-inflammatory cytokines derived from macrophages. 
Oxidative stress and inflammation are closely related to each other and create a vicious cycle in the diabetic state. Gorin et al. [38] showed that NADPH oxidase, and especially the NOX4 component of NADPH in the kidney, is important as the major source of oxidative stress in streptozotocin-induced diabetic nephropathy. Although many stimuli activate NOX4 production, cytokines and shear stress are important factors in the diabetic state [39]. NOX4 has been reported to be produced on epithelial cells [40] and mesangial cells [27], and was confirmed to be produced on endothelial cells in this study. In our study, exendin-4 suppressed NOX4 levels in the kidney. We speculate that reducing the release of pro-inflammatory cytokines from macrophages and normalising hyperfiltration by exendin- 4 treatment may have contributed to the suppression of NOX4 production. Etoh et al. [27] reported that localisation and levels of NOX4 were in parallel with those of 8-OHdG. Therefore, the reduction of NOX4 level by exendin- 4 treatment would contribute to a decrease in 8OHdG production in glomeruli. Park et al. [25] also reported similar results in regard to $8-\mathrm{OHdG}$ reduction by exendin-4 in a mouse model of type 2 diabetes. We speculate that exendin- 4 contributes to an attenuation of oxidative stress and that this helps ameliorate diabetic vascular complications.

It is well known that GLP-1 signalling through GLP-1R enhances cyclic AMP as a second messenger [41]. Previous reports have revealed that an increase in activity of the cyclic AMP/protein kinase A pathway suppresses NF-KB activity in THP-1 cells and HUVECs [42], and inhibits NADPH oxidase [43]. These findings support our finding that exendin- 4 modulated the inflammatory vicious cycle in the kidney.

In our model, exendin-4 did not affect blood glucose levels, blood pressure, food intake or body weight as it has been shown to do in models of type 2 diabetes. To determine that the effects of exendin- 4 occurred without lowering of blood glucose, we started exendin-4 treatment at 1 week after the streptozotocin injections and confirmed that exendin-4 did not restore insulin secretion in our model. A much higher dose than that used in our study would have been necessary to reduce blood pressure in diabetic rats [26]. GLP-1 inhibits food intake and results in weight loss $[18,20,21]$. In the present study, the non-diabetic group treated with exendin-4 had decreased food intake and weight loss compared with the control group, but there were no significant differences. It is difficult to differentiate the effect of exendin-4 from the significant weight reduction that is generally seen in the model of type 1 diabetes.

In this study, the ratio of kidney weight to body weight in the diabetic groups was significantly increased in diabetic rats compared with the non-diabetic groups. However, exendin-4 treatment did not affect them. As periodic acid-Schiff's reagent staining revealed, exendin-4 did not ameliorate tubular hypertrophy. Tubular hypertrophy may be the main factor contributing to kidney weight, and we need to investigate a longer period to appreciate the effect of exendin-4 on tubular hypertrophy and interstitial fibrosis. Additionally, exendin-4 prevented diabetesinduced hyperfiltration. Previous reports have revealed that hyperfiltration was improved by exendin- 4 treatment in obese diabetic patients [44] and the $d b / d b$ mouse model [25]. There has been no report that exendin-4 affects creatinine clearance in a later stage of diabetic nephropathy.

The inflammatory process is involved in the mechanism of obesity-related insulin resistance [45] and in the pathogenesis of atherosclerosis [46]. Moreover, there is also a close relationship between chronic renal insufficiency and the cardiorenal syndrome, through several pathways including inflammation $[47,48]$. GLP-1R agonists might be beneficial for these diseases through their anti-inflammatory effects. Recently, Arakawa et al. [37] reported an antiinflammatory effect of exendin-4 in an animal model of atherosclerosis. Their report also pointed out the importance of exendin- 4 as a potential therapeutic agent for cardiovascular disease in diabetes.

In conclusion, we have shown that exendin- 4 exerts renoprotective effects through anti-inflammatory actions without lowering blood glucose in a streptozotocin-induced rat model of type 1 diabetes. Furthermore, exendin- 4 directly acted on GLP-1R and suppressed production of pro-inflammatory cytokines and ICAM-1. This study may provide the first evidence that GLP-1R agonists directly contribute to the prevention of diabetic nephropathy via an anti-inflammatory effect.

Acknowledgements This study was supported in part by a Grant-inAid for Scientific Research from the Ministry of Education, Science, Culture, Sports and Technology (C21591031 to K. Shikata), and the Ministry of Health, Labour and Welfare of Japan.

Duality of interest The authors declare that there is no duality of interest associated with this manuscript.

\section{References}

1. de Zeeuw D, Parving HH, Henning RH (2006) Microalbuminuria as an early marker for cardiovascular disease. J Am Soc Nephrol 17:2100-2105

2. Go AS, Chertow GM, Fan D, McCulloch CE, Hsu CY (2004) Chronic kidney disease and the risks of death, cardiovascular events, and hospitalization. N Engl J Med 351:1296-1305

3. Magee GM, Bilous RW, Cardwell CR, Hunter SJ, Kee F, Fogarty DG (2009) Is hyperfiltration associated with the future risk of developing diabetic nephropathy? A meta-analysis. Diabetologia 52:691-697 
4. Baynes JW (1991) Role of oxidative stress in development of complications in diabetes. Diabetes 40:405-412

5. Brownlee M, Cerami A, Vlassara H (1988) Advanced glycosylation end products in tissue and the biochemical basis of diabetic complications. N Engl J Med 318:1315-1321

6. Koya D, Jirousek MR, Lin YW, Ishii H, Kuboki K, King GL (1997) Characterization of protein kinase C beta isoform activation on the gene expression of transforming growth factorbeta, extracellular matrix components, and prostanoids in the glomeruli of diabetic rats. J Clin Invest 100:115-126

7. Ziyadeh FN, Sharma K, Ericksen M, Wolf G (1994) Stimulation of collagen gene expression and protein synthesis in murine mesangial cells by high glucose is mediated by autocrine activation of transforming growth factor-beta. J Clin Invest 93:536-542

8. Nelson CL, Karschimkus CS, Dragicevic G et al (2005) Systemic and vascular inflammation is elevated in early $\operatorname{IgA}$ and type 1 diabetic nephropathies and relates to vascular disease risk factors and renal function. Nephrol Dial Transplant 20:2420-2426

9. Saraheimo M, Teppo AM, Forsblom C, Fagerudd J, Groop PH (2003) Diabetic nephropathy is associated with low-grade inflammation in type 1 diabetic patients. Diabetologia 46:1402-1407

10. Furuta T, Saito T, Ootaka T et al (1993) The role of macrophages in diabetic glomerulosclerosis. Am J Kidney Dis 21:480-485

11. Hirata K, Shikata K, Matsuda M et al (1998) Increased expression of selectins in kidneys of patients with diabetic nephropathy. Diabetologia 41:185-192

12. Sugimoto H, Shikata K, Hirata K et al (1997) Increased expression of intercellular adhesion molecule-1 (ICAM-1) in diabetic rat glomeruli: glomerular hyperfiltration is a potential mechanism of ICAM-1 upregulation. Diabetes 46:2075-2081

13. Okada S, Shikata K, Matsuda M et al (2003) Intercellular adhesion molecule-1-deficient mice are resistant against renal injury after induction of diabetes. Diabetes 52:2586-2593

14. Yozai K, Shikata K, Sasaki M et al (2005) Methotrexate prevents renal injury in experimental diabetic rats via anti-inflammatory actions. J Am Soc Nephrol 16:3326-3338

15. Tone A, Shikata K, Sasaki M et al (2005) Erythromycin ameliorates renal injury via anti-inflammatory effects in experimental diabetic rats. Diabetologia 48:2402-2411

16. Ohga S, Shikata K, Yozai K et al (2007) Thiazolidinedione ameliorates renal injury in experimental diabetic rats through antiinflammatory effects mediated by inhibition of NF-kappaB activation. Am J Physiol Renal Physiol 292:F1141-F1150

17. Usui H, Shikata K, Matsuda M et al (2003) HMG-CoA reductase inhibitor ameliorates diabetic nephropathy by its pleiotropic effects in rats. Nephrol Dial Transplant 18:265-272

18. Baggio LL, Drucker DJ (2007) Biology of incretins: GLP-1 and GIP. Gastroenterology 132:2131-2157

19. Farilla L, Hui H, Bertolotto C et al (2002) Glucagon-like peptide1 promotes islet cell growth and inhibits apoptosis in Zucker diabetic rats. Endocrinology 143:4397-4408

20. Nauck MA, Niedereichholz U, Ettler R et al (1997) Glucagon-like peptide 1 inhibition of gastric emptying outweighs its insulinotropic effects in healthy humans. Am J Physiol 273:E981-E988

21. Turton MD, O'Shea D, Gunn I et al (1996) A role for glucagon-like peptide-1 in the central regulation of feeding. Nature 379:69-72

22. Orskov C, Wettergren A, Holst JJ (1993) Biological effects and metabolic rates of glucagon like peptide-1 7-36 amide and glucagon like peptide-1 7-37 in healthy subjects are indistinguishable. Diabetes 42:658-661

23. Bullock BP, Heller RS, Habener JF (1996) Tissue distribution of messenger ribonucleic acid encoding the rat glucagon-like peptide-1 receptor. Endocrinology 137:2968-2978

24. Schlatter P, Beglinger C, Drewe J, Gutmann H (2007) Glucagonlike peptide 1 receptor expression in primary porcine proximal tubular cells. Regul Pept 141:120-128
25. Park CW, Kim HW, Ko SH et al (2007) Long-term treatment of glucagon-like peptide-1 analog exendin-4 ameliorates diabetic nephropathy through improving metabolic anomalies in $\mathrm{db} / \mathrm{db}$ mice. J Am Soc Nephrol 18:1227-1238

26. Hirata K, Kume S, Araki S et al (2009) Exendin-4 has an antihypertensive effect in salt-sensitive mice model. Biochem Biophys Res Commun 380:44-49

27. Etoh T, Inoguchi T, Kakimoto $M$ et al (2003) Increased expression of $\mathrm{NAD}(\mathrm{P}) \mathrm{H}$ oxidase subunits, NOX4 and p22phox, in the kidney of streptozotocin-induced diabetic rats and its reversibity by interventive insulin treatment. Diabetologia 46:1428-1437

28. Fong JS, Drummond KN (1968) Method for preparation of glomeruli for metabolic studies. J Lab Clin Med 71:1034-1039

29. Shigenaga MK, Gimeno CJ, Ames BN (1989) Urinary 8-hydroxy2 -deoxyguanosine as a biological marker of in vivo oxidative DNA damage. Proc Natl Acad Sci U S A 86:9697-9701

30. Liu H, Dear AE, Knudsen LB, Simpson RW (2009) A long-acting glucagon-like peptide-1 analogue attenuates induction of plasminogen activator inhibitor type-1 and vascular adhesion molecules. J Endocrinol 201:59-66

31. Pawluczyk IZ, Harris KP (1997) Macrophages promote prosclerotic responses in cultured rat mesangial cells: a mechanism for the initiation of glomerulosclerosis. J Am Soc Nephrol 8:1525-1536

32. Leonarduzzi G, Scavazza A, Biasi F et al (1997) The lipid peroxidation end product 4-hydroxy-2,3-nonenal up-regulates transforming growth factor betal expression in the macrophage lineage: a link between oxidative injury and fibrosclerosis. Faseb J $11: 851-857$

33. Ziyadeh FN, Hoffman BB, Han DC et al (2000) Long-term prevention of renal insufficiency, excess matrix gene expression, and glomerular mesangial matrix expansion by treatment with monoclonal antitransforming growth factor-beta antibody in $d b / d b$ diabetic mice. Proc Natl Acad Sci U S A 97:80158020

34. Sharma K, Ziyadeh FN (1995) Hyperglycemia and diabetic kidney disease. The case for transforming growth factor-beta as a key mediator. Diabetes 44:1139-1146

35. Guijarro C, Egido J (2001) Transcription factor-kappa B (NFkappa B) and renal disease. Kidney Int 59:415-424

36. Roebuck KA, Finnegan A (1999) Regulation of intercellular adhesion molecule-1 (CD54) gene expression. J Leukoc Biol 66:876-888

37. Arakawa M, Mita T, Azuma K et al (2010) Inhibition of monocyte adhesion to endothelial cells and attenuation of atherosclerotic lesion by a glucagon-like peptide-1 receptor agonist, exendin-4. Diabetes 59:1030-1037

38. Gorin Y, Block K, Hernandez J et al (2005) Nox4 NAD(P)H oxidase mediates hypertrophy and fibronectin expression in the diabetic kidney. J Biol Chem 280:39616-39626

39. Frey RS, Ushio-Fukai M, Malik AB (2009) NADPH oxidasedependent signaling in endothelial cells: role in physiology and pathophysiology. Antioxid Redox Signal 11:791-810

40. Sharma K, Ramachandrarao S, Qiu G et al (2008) Adiponectin regulates albuminuria and podocyte function in mice. $\mathrm{J}$ Clin Invest 118:1645-1656

41. Doyle ME, Egan JM (2007) Mechanisms of action of glucagon-like peptide 1 in the pancreas. Pharmacol Ther 113:546-593

42. Ollivier V, Parry GC, Cobb RR, de Prost D, Mackman N (1996) Elevated cyclic AMP inhibits NF-kappaB-mediated transcription in human monocytic cells and endothelial cells. J Biol Chem 271:20828-20835

43. Kim JS, Diebold BA, Babior BM, Knaus UG, Bokoch GM (2007) Regulation of Nox1 activity via protein kinase A-mediated 
phosphorylation of NoxA1 and 14-3-3 binding. J Biol Chem 282:34787-34800

44. Gutzwiller JP, Tschopp S, Bock A et al (2004) Glucagon-like peptide 1 induces natriuresis in healthy subjects and in insulin-resistant obese men. J Clin Endocrinol Metab 89:3055-3061

45. Xu H, Barnes GT, Yang Q et al (2003) Chronic inflammation in fat plays a crucial role in the development of obesity-related insulin resistance. J Clin Invest 112:1821-1830
46. Ross R (1999) Atherosclerosis - an inflammatory disease. N Engl J Med 340:115-126

47. Bongartz LG, Cramer MJ, Doevendans PA, Joles JA, Braam B (2005) The severe cardiorenal syndrome: 'Guyton revisited'. Eur Heart J 26:11-17

48. Nakamura A, Shikata K, Hiramatsu M et al (2005) Serum interleukin-18 levels are associated with nephropathy and atherosclerosis in Japanese patients with type 2 diabetes. Diabetes Care 28:2890-2895 